\title{
Cropland Abandonment in the Community-Forestry Landscape in the Middle Hills of Nepal
}

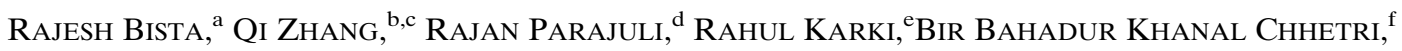 \\ AND CONGHE SONG ${ }^{\text {a,g }}$ \\ ${ }^{a}$ Department of Geography, University of North Carolina at Chapel Hill, Chapel Hill, North Carolina \\ ${ }^{\mathrm{b}}$ Department of Earth and Environment, Boston University, Boston, Massachusetts \\ ${ }^{\mathrm{c}}$ Frederick S. Pardee Center for the Study of the Longer-Range Future, Boston University, Boston, Massachusetts \\ ${ }^{\mathrm{d}}$ College of Natural Resources, North Carolina State University, Raleigh, North Carolina \\ ${ }^{\mathrm{e}}$ ForestAction, Lalitpur, Nepal \\ ${ }^{\mathrm{f}}$ Department of Social Forestry and Forest Management, Institute of Forestry, Tribhuvan University, Kirtipur, Nepal \\ ${ }^{g}$ Carolina Population Center, Chapel Hill, North Carolina
}

(Manuscript received 23 February 2021, in final form 19 July 2021)

\begin{abstract}
Cropland abandonment has been a major land-use concern, threatening food security globally. Understanding the factors contributing to cropland abandonment advances land-use change science and provides essential information for policy making, both of which aim to improve agriculture land management. Despite many studies conducted on this topic, we still lack in-depth understanding on how feedbacks from the natural system influence cropland-use decisions at the household level in the human system. We fill this knowledge gap by conducting this study in the Middle Hills of Nepal, where community forestry is an integral part of the land-use system. We collected qualitative data through focus-group discussions, key-informant interviews, and review of local community-forest management documents, and we collected quantitative socioeconomic data through a household survey of 415 households. We geolocated 1264 cropland parcels owned by these households and recorded their use statuses. We found that there is an increasing trend of cropland abandonment that is due to multiple socioeconomic, ecological, and biophysical factors. A higher likelihood of cropland abandonment is linked to households that have more outmigrants, female heads, nonagricultural occupation of the household heads, and larger areas of agriculture landholding. The study also found that cropland parcels that are far from the households, close to the forest edge, and on steeper slopes are more likely to be abandoned. These findings provide key information for policy makers to devise effective measures on managing cropland and developing sustainable agriculture in rural Nepal.
\end{abstract}

KEYWORDS: Feedback; Regression analysis; Agriculture; Geographic information systems (GIS); Land use; Societal impacts

\section{Introduction}

Cropland abandonment is a process of withdrawing cropland from active agricultural production without a plan for crop cultivation in the immediate future (Baxter and Calvert 2017). It includes all the landforms in which farming has ceased and is no longer in use as an economic resource. It has been one of the global land-use phenomena for several decades (Jaquet et al. 2015; Prishchepov et al. 2011; Zhang et al. 2014) and has been increasing in many parts of the world (He et al. 2020; Hobbs and Cramer 2007). Studies have provided impressive cropland abandonment statistics. For example, around 52.5 million ha of agricultural land in central and eastern Europe have been abandoned (Alcantara et al. 2013); the area of

Bista's ORCID: 0000-0003-4321-1206.

Song's ORCID: 0000-0002-4099-4906.

Corresponding authors: Rajesh Bista, raaj@live.unc.edu; Dr. Conghe Song, csong@email.unc.edu

Earth Interactions is published jointly by the American Meteorological Society, the American Geophysical Union, and the Association of American Geographers. abandoned agricultural land is about 4.9 million ha in the United States (Baxter and Calvert 2017). In China, the abandoned land occurs mostly in mountainous counties, accounting for $28 \%$ of the total cropland available in these areas ( $\mathrm{Li}$ et al. 2018), while in Japan the proportion of abandoned agriculture land reached $10 \%$ ( $\mathrm{Li}$ and $\mathrm{Li} 2017$ ). At the global scale, approximately 472 million ha of the agricultural land in total has been reported as being abandoned (Campbell et al. 2008; Paudel et al. 2020), which was cultivated actively at some point in time. The widespread abandonment of cropland poses a serious threat to food security for the growing population in many developing countries, particularly in Asia and Africa. Understanding how the underlying factors influence the process of cropland abandonment is essential for making new agricultural policies to stabilize agricultural land use for food security.

Cropland abandonment has both positive and negative consequences on the environment and society. On the one hand, cropland abandonment allows vegetation restoration, increase in carbon sequestration (Benayas et al. 2007; Hobbs and Cramer 2007), soil conservation, and nutrient retention (Blair et al. 2018; Leal Filho et al. 2017; Liu et al. 2008; Li and Li 2017), providing ecological benefits at both the local and global scales (Bowen et al. 2007; Leal Filho et al. 2017). On the other hand, cropland abandonment brings multiple negative consequences, such as soil and land degradation due to lack of soil management activities, the emergence of invasive species, 
the reduction in landscape heterogeneity, the degradation of cultural and aesthetic value, and the reduction in agricultural production that threaten food security (Benayas et al. 2007; Leal Filho et al. 2017; Wang et al. 2017). Vegetation regenerated on abandoned cropland could be of low quality with less economic and ecological values (Bowen et al. 2007). Research conducted in Nepal found four major negative impacts of cropland abandonment. The first is the increase in risk of food insecurity, leading to overdependency on imported agricultural products (Khanal 2018). The second is disruption in intergenerational practices of farmland management through the indigenous labor exchange system and traditional irrigation practice (Chaudhary et al. 2018; Hobbs and Cramer 2007; Jaquet et al. 2015). Third, there are increases in geomorphic damages such as landslide, damage to terrace riser, debris flow, sheet, and gully erosion in abandoned land due to lack of land management (Chaudhary et al. 2020; Khanal and Watanabe 2006; Schwilch et al. 2017). Last, abandoned land tends to be encroached by invasive species, such as Ageratum conyzoides, Eupatorium spp., and Lantana camara (Gilmour et al. 2014; Jaquet et al. 2015), which are more susceptible to fire.

Understanding the extent and factors contributing cropland abandonment is key to address these negative consequences of cropland abandonment. Therefore, this research aims to address the following research questions: 1) What is the existing status of cropland abandonment in the Middle Hills of Nepal? 2) What are the reported reasons of cropland abandonment in the area? 3) How forests near cropland contribute to cropland abandonment on top of other socioeconomic and environmental factors?

Nepal is a mountainous agricultural country, with more than $60 \%$ of the population engaged in farming on about $21 \%$ of the country's land that are arable (Bhattarai and Conway 2021; Ministry of Agricultural Development 2015; National Planning Commission 2019). Like many other countries around the world (Alcantara et al. 2013; Li et al. 2018), Nepal has been witnessing a rising trend in cropland abandonment, mainly in the Middle Hills region in recent years (Narendra et al. 2019). Although cropland abandonment will ultimately affect the livelihood stability of farm household as well as the country's food security, limited studies based on first-hand data collected on the ground have examined the driving factors of this issue. An assessment using the secondary data estimated that around $24 \%$ of the cultivated farmland in Nepal were abandoned (Chaudhary et al. 2020; Ministry of Agriculture and Livestock Development 2020). Another watershed-level study conducted in the Middle Hills of Nepal reported a similar proportion (22\%) of cropland abandonment (Jaquet et al. 2015). Despite being an agrarian economy with more than $60 \%$ farming households, Nepal cannot produce enough food to be selfsufficient (Sunam 2020). The contribution to Nepal's GDP from the agricultural sector dropped from $40 \%$ in 1995 to $27 \%$ in 2019 (National Planning Commission 2019). Nepal used to produce surplus agriculture crops prior to 1980 s, but in recent years, agricultural imports have increased significantly. Notably, from 2010 to 2015, agriculture imports increased by $55 \%$ from $\$ 621$ million to $\$ 1.4$ billion (U.S. dollars; Ministry of Agricultural Development 2015). A recent assessment concluded that Nepal annually imports $\$ 600$ million equivalent of grain, fruits, and vegetables (Bhattarai et al. 2020), and the gap between imports and exports is widening every year (Bhattarai and Conway 2021). Despite the dreadful situation of growing food insecurity, growing food trade deficit, and malnutrition (Ministry of Agricultural Development 2015), Nepal is experiencing cropland abandonment. Therefore, comprehensive understanding of factors that affect cropland abandonment is urgently needed for making policies to remedy the situation.

Although cropland abandonment in Nepal is well acknowledged, few empirical studies have been conducted to explore the current state of cropland abandonment and its driving factors. Some studies have identified rural out-migration as a major contributing factor to cropland abandonment (Bhawana and Race 2020a; Jaquet et al. 2019; Ojha et al. 2017). Nevertheless, they have mostly overlooked locational factors as well as cropland and farm household characteristics that could drive the cropland abandonment (L. Zhang et al. 2018; Q. Zhang et al. 2018; Zhou et al. 2020). Cropland abandoned in most cases are due to the process of economic marginalization driven by interactions of multiple social-economic, political, geographical, and environmental factors (Baxter and Calvert 2017; Leal Filho et al. 2017), which all vary with the local circumstances (Paudel et al. 2019; Su et al. 2018).

Although studies have identified demographic, economic, sociocultural, institutional factors as underlying drivers for agriculture land-use change (Geist and Lambin 2002; van Vliet et al. 2015), the role of forest as an ecological factor to cropland abandonment has not been well understood. Following the initiation of community forestry, most of the forest areas near the communities and agriculture land have been well stocked and have served as a habitat for wild animals (Chaudhary et al. 2018; Anup 2017; Shrestha and Paudel 2018). The presence of forest near cropland have made the crops prone to wildlife damage (Naughton-Treves et al. 1998; Priston and Underdown 2009). Moreover, it has made crops more susceptible to competition for sunlight, water, and nutrients from adjacent trees, which is generally understood as the "shading effect" (Hua et al. 2016; Jose et al. 2008; Schmidt et al. 2019; Sharif et al. 2010). However, the pathways of cropland abandonment due to crop raiding and decreasing productivity caused by the shading effect have not been empirically studied. This study collected first-hand data via household surveys, allowing us to account for farmers perceptions on cropland use. Hence, this study will fill in critical knowledge gaps in our understanding on the feedback effects from the natural system to cropland use. The rest of the paper is organized as follows: Section 2 presents theoretical background of the study. Brief descriptions of the materials and methods are provided in section 3. Section 4 describes the major findings, section 5 provides a discussion of the results, and the last section has concluding remarks.

\section{Theoretical background}

Land-use science is a fundamental component of global environmental change and sustainability research (Rindfuss et al. 2004; Turner et al. 2007; Rudel et al. 2005). The agriculture land-use change process is context specific and occurs as a result of interactions of multiple socioeconomic, ecological, 
and geographic factors (Benayas et al. 2007; Hobbs and Cramer 2007; Leal Filho et al. 2017; Li and Li 2017; Pan and Bilsborrow 2005; Su et al. 2018). Studies on agriculture land-use change have identified demographic processes, macroeconomics, policy and institutional arrangements, technology, and culture as the primary driving factors (Lambin et al. 2001, Lambin et al. 2003; Rindfuss 2008), and they emphasize the need for integration of socioeconomic and biophysical systems to understand the landuse dynamics (Lambin and Meyfroidt 2010; Turner et al. 2007, 2020). Socioeconomic factors drive the use of natural resources and land, which alters the ecosystem goods and services, consequently feeding back to land-use decisions. The effects of feedbacks from the natural system to land-use change has not been well integrated to the current land-use change theory.

Cropland abandonment usually occurs when crop production is no longer profitable (Baxter and Calvert 2017), as can be caused by either the biophysical conditions of the land per se or socioeconomic conditions of the land users. Multiple biophysical conditions may contribute to marginal conditions of cropland (Díaz et al. 2011; Li and Li 2017), leading to cropland abandonment, such as low soil quality, steep slopes, high elevation, unreliable climate (Benayas et al. 2007; Díaz et al. 2011). In addition, locational characteristics such as distance to the parcel, distance to the forest from parcel, and distance from the road networks also affect the likelihood of cropland being abandoned. Numerous socioeconomic factors also contribute to cropland abandonment, including economic volatility from subsistence farming, remittance and other household income, farm size, out-migration, and farm labor availability (Benayas et al. 2007; Jaquet et al. 2015). Access to and distribution of economic resources vary with caste-based norms and networks and thus have influence on agriculture land use (Bhawana and Race 2020a). At the individual level, farmer attributes such as education, age, off-farm employment, and gender also affect cropland abandonment. These factors often do not function in isolation; their interactions lead to cropland abandonment to be context specific and varies at different spatial and temporal scales (de Jong et al. 2017).

In Nepal, agriculture practices are influenced by multiple factors, including exodus of working laborers mostly from rural areas (Bhawana and Race 2020a; Jaquet et al. 2015), changing households demographics and increasing reliance on female headed households for agriculture (Bhawana and Race 2020b), land fragmentation (Naya et al. 2014), soil degradation and decreasing per capita production (Chalise et al. 2019; Deshar 2013), lack of irrigation and increasing impacts of climate change (Bhattarai and Conway 2021; Gauchan 2018), and topographic characteristics such as steep slopes and topographic ruggedness (Bhattarai et al. 2020). Livelihood alternatives (Chaudhary et al. 2020), subsistence based agricultural practice and its lower profitability (Gauchan 2018), and lack of development plans are additional challenges for sustainable agriculture in Nepal. Moreover, a few recent studies found crop raiding as emerging issues affecting agricultural practices in the Middle Hills of Nepal (Bhawana and Race 2020a; Paudel et al. 2020).

Thanks to community forestry (CF), most of the accessible and degraded forest conditions improved significantly in the past a few decades in Nepal (Ministry of Forests and Soil
Conservation 2013). CF is a forest management strategy that devolved forest management rights to the local communities with the dual goal of forest conservation and livelihood improvement (Department of Forest Research and Survey 2015; Ministry of Forests and Soil Conservation 2013). Around 35\% (out of 6.6 million ha) of the forests in Nepal are now managed by more than 23000 community-forest user groups (CFUGs), which encompass 2.5 million households (Dhruba Bijaya et al. 2016). CF is an integral part of agriculture landscape in the Middle Hills of Nepal. On average, Nepali rural households own 0.6 ha of agricultural land, whereas they have access to an average of 0.7 ha of community forests (Karki et al. 2018; Naya et al. 2014). In the last two decades, forest coverage in Nepal increased from $37 \%$ to $45 \%$, which is mainly attributable to the CF (Department of Forest Research and Survey 2015; Forest Research and Training Centre 2019). Studies have shown that community forests were effective at conserving biodiversity and preserving habitats for wildlife, similar to other stricter protection regimes (Fischer et al. 2008; Goswami et al. 2014; Anup 2017; Schuster et al. 2019). The improvement of forest conditions by $\mathrm{CF}$ attracted wildlife, leading to increase in human-wildlife conflicts around community forests (Hua et al. 2016; Anup 2017). Crop raiding by wildlife is a major form of human-wildlife conflict in the Middle Hills of Nepal. Such conflict may significantly influence the rural household landuse decision. Moreover, farmers increasingly perceive $\mathrm{CF}$ as a negative factor to crop yield as a result of "shading effect" on adjacent croplands. Crops compete for nutrients, water, and sunlight with forests nearby (Jose et al. 2008; Lin et al. 1998). Recent international workshop on "women in agroforestry" conducted in Nepal highlighted the possibility of shading effects to agriculture from trees (Amatya et al. 2018).

\section{Methods and materials}

\section{a. Study areas}

This study was conducted in the Kavrepalanchowk and Tanahu districts in province 3 and 4, respectively (Fig. 1). Both districts are dominated by hilly terrain, with most of the people depending on agriculture for livelihoods. The elevation of Kavrepalanchowk district ranges over approximately 300$3000 \mathrm{~m}$ above mean sea level, with a total area of 1.40 million ha. Similarly, the elevation of Tanahu ranges from 186 to $2325 \mathrm{~m}$ above mean sea level, with a total area of 1.56 million ha. Kavrepalanchowk is covered by 73075 ha $(52.02 \%)$ of forests with more than 559 CFUGs, and Tanahu has a total forest area of 82249 ha $(52.61 \%)$ with 616 CFUGs (District Forest Office 2018, 2019). Because of variation in topography, agriculture practices are diverse even within the same district. Two categories of cropland-khet and bari-are observed in the two study sites. The khet is relatively productive, usually with access to irrigation. Rice and wheat are the two major crops grown on khet. The bari is rainfed cropland with no access to irrigation, where grains like millet and maize are grown. The khet is generally recognized as lowland, and the bari is recognized as highland (Bhawana and Race 2020b). Agriculture and animal husbandry integrated with forestry is the dominant livelihood options in the study areas. Table 1 

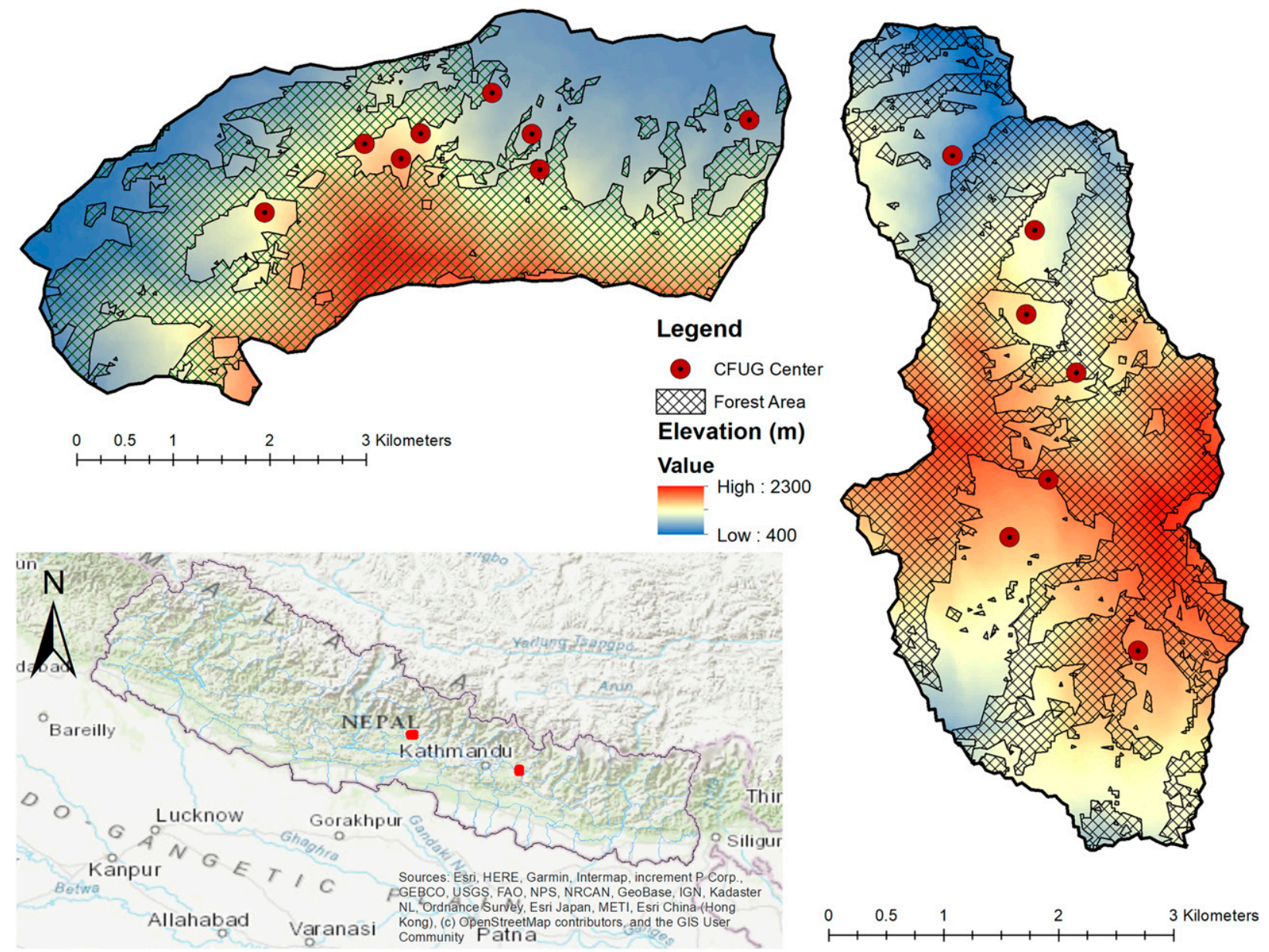

FIG. 1. Map of the study area, showing the location of the two study sites: Kavrepalanchowk is $35 \mathrm{~km}$ to the east of Kathmandu (right map), and Tanahu is $100 \mathrm{~km}$ west of Kathmandu (top map).

presents additional background information on location, climate, area, altitude range, and vegetation types in the regions covering the two study sites.

Three criteria were considered for selecting the study sites: 1) prevalence of abandonment of the croplands, 2) livelihoods dependent on crops and livestock farming, and 3) existence of CFUGs. The Kavrepalanchowk district has 13158 ha (of 61598 ha) of abandoned cropland (District Forest Office 2018), and the Tanahu district has 13418ha (of 65061 ha) of abandoned cropland (District Forest Office 2019). The communities in both study areas have been successfully conserving forests through CF for a few decades and are experiencing crop raiding from wild animals in recent years.

\section{b. Data collection}

The data were collected in the summers of 2018 and 2019 through household surveys with a questionnaire, focus-group discussions, key-informant interviews, and content review of the CFUG operation plan. We also collected the spatial locations of all individual cropland parcels each interviewed household owned and the household residence, with a handheld global positioning system (GPS) unit. The survey adopted a multistage sampling method (Wang et al. 2020). In the first stage, we considered CFUGs as the unit of sampling. A CFUG is a group of households in a community who make management decisions about some forests nearby based on an operation plan approved by the Divisional Forest Office. These forests are designated as community forests. Communities can form CFUGs as per their willingness, capacity, and customary rights. The boundary of community forest is not restricted to the existing administrative boundaries. The two geographic locations were selected purposively after consultations with experts in the ForestAction Nepal [a research nongovernmental organization (NGO) based in Kathmandu] and the Department of Forests and Soil Conservation of the Government of Nepal. CFUGs within each geographic location were selected based on their accessibility and length of community-forestry practice. The second stage of the sampling is selecting households for interview from the selected CFUG in the first stage. The households within a CFUG were selected using a simple random sampling method. In total, 415 households from 15 CFUGs, 215 from the Bhumlu rural municipality in the Kavrepalanchowk district and 200 from the Bhanu municipality in the Tanahu district (Table 1), were interviewed. To connect the household socioeconomic 
TABLE 1. Attributes of community-forest user groups involved in this study at two study sites.

\begin{tabular}{lcc}
\hline & Bhumlu rural municipality 4 & Bhanu municipality 11 \\
\hline District & Kavrepalanchowk & Tanahu \\
No. of studied CFUGs & 7 & 8 \\
Mean household size of CFUGs & 88.57 & 52.25 \\
Mean area of CFUGs (ha) & 50.44 & 20 \\
Total households & 487 & 408 \\
Households interviewed & 215 & 200 \\
No. of cropland parcels geolocated & 543 & 721 \\
Area of study site (ha) & 1600 & 1900 \\
Forest area (\%) & 57 & 55 \\
Agriculture area (\%) & 40.5 & 42 \\
Alt (m MSL) & $950-2250$ & $400-1450$ \\
Mean annual rainfall $(\mathrm{mm})$ & 1923 & 1761 \\
Mean temperature max $\left({ }^{\circ} \mathrm{C}\right)$ & 28.41 & 28.9 \\
Mean temperature min $\left({ }^{\circ} \mathrm{C}\right)$ & 14.04 & 16.6 \\
Vegetation type & Subtropical and temperate & Tropical and subtropical \\
\hline
\end{tabular}

condition with the biophysical condition of the croplands, the geographic coordinates of each cropland parcel owned by the households interviewed were collected with a handheld GARMIN GPS unit. A total of 1264 cropland parcels were geolocated. Because of the limitation of time in the field, it was not possible to delineate the boundary of the cropland parcels; instead, the location of the center of each land parcel or as close as possible to the center was collected, which can be an effective way of connecting socioeconomic data with land-use condition (Rindfuss et al. 2004).

The questionnaire was designed in both English and Nepali and was pretested in the field before conducting the full detailed household survey. Two local interviewers were hired and trained for the household interviews for each study site. The purpose of the research was explained to all of the participants before their participation in the survey, and all of the participants were ensured anonymity and confidentiality of their responses. It was intended to interview the household heads, but if the household head was not available at that time, an adult in the household who managed the day-to-day affairs on the field was selected as the alternative respondent. The questionnaire was designed to collect household socioeconomic information, including demographics, migration, current cropland-use status, participation in the community-forestry programs, household wealth indicators, income and expenditure, crop raiding and livestock depredation by wildlife, and livestock ownership. For each abandoned cropland parcel, the year when the land parcel was left uncultivated, walking distance to the parcel, and reasons for the abandonment were recorded. It took an average of 50-60 min to complete an interview for a single household by a well-trained interviewer. Biophysical parameters including elevation, slope, aspect of the land parcels, and household locations were extracted using geographic information system data (GIS) from a digital elevation model (DEM) based on the coordinates collected in the field. Similarly, using the "generate near table" tools in ArcMap software, the distances from the land parcels to the nearest edge of the forest were calculated. Additional secondary information on district-level CFUG evaluations and monitoring reports, rural municipality profile, and the CFUG operational plan was obtained from government offices. Formal and informal interviews with local-level government authorities, school teachers, and local political leaders were carried out to understand the socioeconomic and political environmental settings in the study sites. All survey protocols were approved by the University of North Carolina Chapel Hill's Institutional Review Board.

\section{c. Multilevel model specification}

A multilevel logistic regression model was employed to assess the effects of determinants of cropland abandonment in the study areas. Since the cropland parcels were clustered into households, the data at the parcel level were not independent, and hence traditional linear and binary models were not appropriate to the data with hierarchical structure. Aggregating the data from the parcels to the households changes their relationship, a phenomenon called "ecological fallacy" (Jefferson et al. 2004; Overmars and Verburg 2006; Pan and Bilsborrow 2005). Ecological fallacies impute the cause of parcel-level patterns to be the same as those operating at a household level. Both aggregating data from parcels to households and disaggregating total cropland areas from households to parcels result in biases in parameter estimates and their standard errors (Guo and Zhao 2000; Overmars and Verburg 2006). Ignoring the multilevel structure of the data can lead to incorrect inferences as it underestimates standard errors of the regression coefficients (Overmars and Verburg 2006; Sommet and Morselli 2017; Wang et al. 2020). The multilevel model corrects the biases on parameter estimates resulting from the clustering of parcellevel variables in the households. This modeling technique also decomposes total variances in the outcome variables and accounts for the variability at each level.

In this study, first a null multilevel model without any explanatory variables was fit to provide reference results of group variance and intraclass correlation. Then a full model was fit. The full random coefficient logistic regression model examines the influence of parcel-level and household-level factors on 
cropland abandonment with both fixed effects of level 1 (parcel) and level 2 (household) variables and random effects of level 2. Within each study site, CFUGs were clustered, and some of the households were members of multiple CFUGs, which inhibited the incorporation of random effects of CFUGs. The dependent variable in this study is a binary variable representing whether the land parcel had been abandoned $(=1)$ or not $(=0)$ at the time of the household survey. The equations below represent the random-intercept two-level null and full models without and with all explanatory variables, respectively:

$$
\begin{aligned}
\log \left[\frac{\operatorname{Pr}\left(Y_{i j}=1\right)}{1-\operatorname{Pr}\left(Y_{i j}=1\right)}\right]= & \beta_{0}+\mu_{j}+\varepsilon_{i j} \quad \text { and } \\
\log \left[\frac{\operatorname{Pr}\left(Y_{i j}=1\right)}{1-\operatorname{Pr}\left(Y_{i j}=1\right)}\right]= & \beta_{0}+\sum_{m=1}^{M} \beta_{m} X_{m i j}+\sum_{n=1}^{N} \gamma_{n} Z_{n j} \\
& +\mu_{j}+\varepsilon_{i j},
\end{aligned}
$$

where $\operatorname{Pr}\left(Y_{i j}=1\right)$ is the probability of cropland abandonment of the $i$ th parcel owned by the $j$ th household; $X_{m i j}$ is the $m$ th predictor variable for the $i$ th cropland parcel of household $j$, and $Z_{n j}$ is the $n$th predictor variable describing characteristics of household $j$ that influence land abandonment; $\beta_{m}$ and $\gamma_{n}$ are the regression coefficients corresponding to $X_{m i j}$ and $Z_{n j}$, respectively. The intercept is captured by the coefficient $\beta_{0} ; \varepsilon_{i j}$ and $\mu_{j}$ capture the random effects at the parcel level and the household level, respectively. Intraclass correlation coefficients $\rho$ were calculated to indicate the proportion of variance explained by the household level using the following formula (Zhang et al. 2014):

$$
\rho=\frac{\operatorname{Var}\left(\mu_{j}\right)}{\operatorname{Var}\left(\mu_{j}\right)+\operatorname{Var}\left(\varepsilon_{i j}\right)} .
$$

Estimated regression coefficients and odds ratios were reported. The odds ratios were obtained by exponentiating the estimated regression coefficients. In addition, the goodness of fit of the models was assessed using a relative operating characteristic (ROC). Models show better fitting effects with the ROC values increasing from 0.5 (completely random) to 1.0 (perfect discriminative) (Wang et al. 2017; Zhang et al. 2014).

\section{d. Selection and definition of the model variables}

One primary interest of this study is to identify the factors that strongly associate with cropland abandonment in the Middle Hills of Nepal. Households in the region, as shown in our study sites, usually own multiple land parcels, and their decisions to use individual land parcels can be affected by household socioeconomic characteristics and land parcel biophysical properties (Islam et al. 2019; Kerckhof et al. 2016; Wang et al. 2020). We selected the variables in the socioeconomic and biophysical domains based on existing land-use change theories and empirical studies as well as our field insights (Blair et al. 2018; Geist and Lambin 2002; Islam et al. 2019; Kerckhof et al. 2016; Lambin et al. 2003; Turner et al. 2007; Wang et al. 2020).

At the parcel level, we used cropland parcels' biophysical properties in the model. We used information from all in-use land parcels and abandoned land parcels since 2014. These variables included parcel area, walking distance from home to the parcel, slope and elevation, land type (khet vs bari), and incidence of crop raiding in a 1-yr period. In addition, we also included the shading effect (binary variable: parcel with or without shading effects) on cropland abandonment. Recent empirical studies have found that the shading effect of forests on the adjacent agriculture land (Miyagawa et al. 2017; Sharif et al. 2010; Suryanto et al. 2014) occurs up to $15 \mathrm{~m}$ from the forest edge for wheat and rice and $30 \mathrm{~m}$ for maize (Schmidt et al. 2019). Parcels close to forests could be less productive due to shading (Jose et al. 2008) and crop raiding by wild animals living there (L. Zhang et al. 2018; Q. Zhang et al. 2018). Studies also suggest that an increase in parcel slope and elevation enhanced the likelihood of cropland abandonment (Leal Filho et al. 2017; Li et al. 2018; Shi et al. 2016). We did not incorporate crop raiding by wild animals in our model because crop raiding was no longer relevant to cropland that had already abandoned.

At the household level, the land-use decision is influenced by multiple underlying drivers, including the attitude of household members toward environmental values, their ability and financial status (Malek et al. 2019), objectives of owning land, occupation, total household income, and cropland size. Since household characteristics can influence resource management decisions, this study accounted for the household head's age, gender, education, number of internal migrants (individual with age between 16 and 65 who left the house for more than six consecutive months), total land area owned, and caste. At the data cleaning process, we found 47 cropland parcels missing GPS coordinates. Moreover, land parcels that were abandoned before 2014 were excluded from our model because the household socioeconomic data collected in 201819 may not apply to the households before 2014. As a result, we had a total of 408 households and 1100 parcel-level data for the modeling analysis. Table 2 provides the explanations and descriptive statistics for parcel and household level explanatory variables used in the model with their expected signs showing relation with dependent variable.

\section{Results}

\section{a. Descriptive statistics of sampled households and their land parcels}

The land parcels were generally small and fragmented in our study sites, with a mean area of $4.07 \pm 4.79$ ropani $^{1}$ for the abandoned parcels and $3.85 \pm 3.09$ ropani for the land parcels in active use. Of the 1100 land parcels surveyed, $35 \%$ of the land was the khet (lowland), and the remaining $65 \%$ was the bari (highland). The mean walking distance from the household residence to the parcel ranged from $14.22 \pm 17.39 \mathrm{~min}$ for cultivated parcels to $24.39 \pm 20.89 \mathrm{~min}$ for abandoned land parcels. The average distances from parcel to the nearest forest

\footnotetext{
${ }^{1}$ Ropani is a unit for land area measurement in Nepal ( 1 ha $=$ 19.65 ropani or 1 ropani $=509 \mathrm{~m}^{2}$ ).
} 
TABLE 2. Descriptive statistics of the variables used in the multilevel models with their expected signs, showing the relationship with the dependent variable.

\begin{tabular}{|c|c|c|c|c|c|c|}
\hline Variable & Description & Mean & Std dev & Min & Max & $\begin{array}{c}\text { Expected } \\
\text { sign }\end{array}$ \\
\hline \multicolumn{7}{|c|}{ Dependent variable (parcel level; $n=1100$ ) } \\
\hline \multicolumn{7}{|c|}{ Explanatory variable } \\
\hline Level 1 (parcel level; $n=$ & 100) & & & & & \\
\hline Area of parcel & Area of land parcel (ropani) & 3.88 & 3.39 & 0.3 & 46 & \pm \\
\hline Parcel type & $0=$ Khet $^{\mathrm{a}} ; 1=$ Bari $^{\mathrm{b}}$ & 0.64 & 0.47 & 0 & 1 & \pm \\
\hline Parcel distance & $\begin{array}{l}\text { Walking distance from home to land parcel (in } \\
\text { minutes) }\end{array}$ & 15.74 & 18.31 & 1 & 150 & + \\
\hline Distance to forest & Distance to nearest forest edge $(\mathrm{m})$ & 78.56 & 89.51 & 0 & 620.21 & - \\
\hline Slope & In degrees & 18.07 & 9.93 & 0 & 58.57 & + \\
\hline Elev & Elevation of parcel (in 100s of meters) & 12.40 & 4.87 & 4.67 & 20.79 & \pm \\
\hline Shading effect & $\begin{array}{l}\text { Parcel with shading effect on agriculture crops } \\
(0=\text { no shading effects; } 1=\text { shading effects })\end{array}$ & 0.32 & 0.46 & 0 & 1 & + \\
\hline \multicolumn{7}{|c|}{ Level 2 [household $(\mathrm{HH})$ level; $n=408$ ] } \\
\hline Cropland area & Total area of cropland owned by HH (ropani) & 12.79 & 10.13 & 0.9 & 108.8 & \pm \\
\hline Occupation & $\begin{array}{l}0 \text { if } \mathrm{HH} \text { head major occupation is agriculture and } \\
1 \text { if otherwise }\end{array}$ & 0.58 & 0.49 & 0 & 1 & + \\
\hline Age & Age of HH head in year of survey (in years) & 54.22 & 13.94 & 22 & 85 & \pm \\
\hline Education & Years of schooling of $\mathrm{HH}$ head & 4.29 & 3.8 & 0 & 16 & + \\
\hline Gender & Gender of $\mathrm{HH}$ head $(0=$ female; $1=$ male $)$ & 0.73 & 0.44 & 0 & 1 & - \\
\hline No. of migrants & No. of active population internal migrants at $\mathrm{HH}$ & 1.30 & 1.53 & 0 & 8 & + \\
\hline Sites & $0=$ Kavrepalanchowk $; 1=$ Tanahu & 0.47 & 0.49 & 0 & 1 & \pm \\
\hline
\end{tabular}

${ }^{a}$ Khet: Paddy land with possibility of irrigation, also called lowland.

${ }^{\mathrm{b}}$ Bari: High land with no measure of irrigation, mostly cultivate dry crops.

edge were $82.63 \pm 91.39$ and $54.25 \pm 73 \mathrm{~m}$ for cultivated and abandoned land parcels, respectively. Meanwhile, $15 \%$ of the land parcels experienced shading effects. The average slope was $17.7^{\circ} \pm 10.2^{\circ}$ for cultivated land parcels and $20.5^{\circ} \pm 10.1^{\circ}$ for abandoned parcels, ranging from $0^{\circ}$ to $58^{\circ}$ for both types. The elevation of land parcels ranged from 487 to $2095 \mathrm{~m}$, with an average of $1240 \pm 467 \mathrm{~m}$ (Table 2 ). There was a significant difference between abandoned and cultivated land parcels in terms of elevation, slope, distance to the nearest forest edge, shading effects, and walking distance from the house location to the land parcels, whereas the parcel area and land types did not differ significantly (Table 3).

In the study sites, individual households had an average household size of $5.5 \pm 1.97$, with $12.79 \pm 10.13$ ropani of land owned. Like other developing countries, remittance from migrants was the major source of household income, with an average of 1.3 persons as domestic migrants per household. Of the 408 households, $44.5 \%$ were Brahmin/Chettri (prevailing class caste group), 26\% were Dalit (marginalized caste group), and $29.5 \%$ were Janajati (indigenous caste group). Similarly, the average walking distance to cropland parcels from the household residence was $15.75 \pm 18.31 \mathrm{~min}$. On average, an individual household owned $2.6 \pm 1.2$ land parcels in the form of dry cropland (bari) and rainfed cropland (khet). The average age of the household heads was $54.2 \pm 14 \mathrm{yr}$, with an education of around $4 \pm 3.8 \mathrm{yr}$. One-quarter of the household heads were female, and $42 \%$ of the household heads were involved in agriculture as the major occupation. On average, an

TABLE 3. Summary statistics and $t$ tests of the mean difference for the parcel level variables between parcels in use and parcels abandoned. Numbers in parentheses are standard deviations. One, two, and three asterisks indicate significance levels $p<0.05, p<0.01$, and $p<0.001$, respectively.

\begin{tabular}{|c|c|c|c|c|}
\hline Variable & Description & Active parcel & Abandoned parcel & Diff in means \\
\hline Area of parcel & Area of individual land parcel & $3.85(3.09)$ & $4.07(4.79)$ & -0.21 \\
\hline Parcel type & $(1=$ khet $; 0=$ bari $)$ & $0.64(0.47)$ & $0.647(0.47)$ & -0.02 \\
\hline Parcel distance & $\begin{array}{l}\text { Walking distance from home to land } \\
\text { parcel (in minutes) }\end{array}$ & $14.22(17.39)$ & $24.39(20.89)$ & $-10.17^{* * * *}$ \\
\hline Distance to forest & Nearest distance to forest edge & $82.63(91.39)$ & $54.25(73)$ & $28.38^{* * * *}$ \\
\hline Shading effect & $0=$ no shading effect; $1=$ shading effect & $0.30(0.46)$ & $0.41(0.49)$ & $-0.112^{* *}$ \\
\hline Slope & Slope of land parcel & $17.66(9.85)$ & $20.52(10.12)$ & $-2.85^{* *}$ \\
\hline Elev & Elev from sea level (in $100 \mathrm{~m}$ ) & $12.58(4.75)$ & $11.34(4.01)$ & $1.24^{* * * *}$ \\
\hline
\end{tabular}




\section{Trend of Cropland Abandonment}

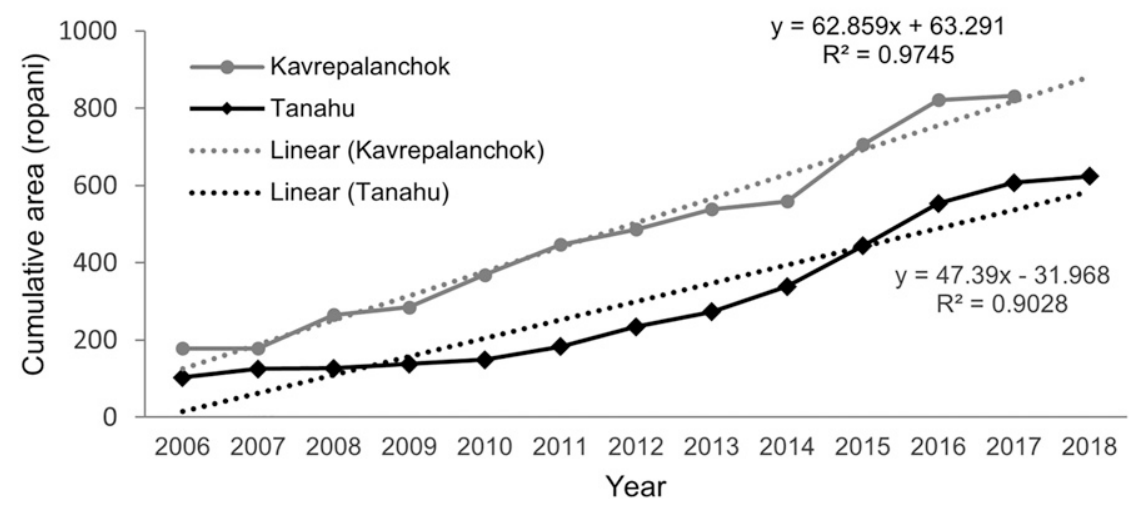

FIG. 2. Trends of cumulative cropland abandonment in the two study sites, Kavrepalanchowk and Tanahu, from 2006 to 2018.

individual household had $2.9 \pm 1.7$ units of livestock, and almost $95 \%$ of the households had at least one kind of livestock.

\section{b. Status and trends of cropland abandonment}

About $38 \%$ of the households had abandoned cropland, which accounted for $27 \%$ of the total cropland area. The area abandoned was $32.1 \%$ of total khet and $24.3 \%$ of total bari. Out of 1264 land parcels owned by 415 households, 341 (26\%) land parcels were abandoned, including 134 from Kavrepalanchowk ( $23.7 \%$ of total land parcels in Kavrepalanchowk) and 207 from Tanahu $(27.8 \%$ of total land parcels in Tanahu). A remarkable number of abandoned parcels regenerated into shrubland and grassland because of the absence of any active intervention by the landowner.

The year 2006 was set as the starting year to analyze the trend of cropland abandonment. This was primarily because the country had suffered from a decade-long armed civil war that ended in 2006. Some of the previous studies have concluded that the end of civil war in 2006 was the beginning era for increasing rates of cropland abandonment in Nepal (Bhattarai et al. 2020; Bhattarai and Conway 2021). Before 2006, only 28 land parcels (103 ropani) in Tanahu and 44 land parcels (178 ropani) in Kavrepalanchowk were abandoned.
Since the number of abandoned land parcel could increase with the land fragmentation process, we considered the total area to understand the trend of cropland abandonment. According to the data collected from the household survey, cropland abandonment had increased rapidly in the recent years (Fig. 2). By 2018, around 949 ropani of land in Kavrepalanchowk and 623 ropani in Tanahu were abandoned. There was a slight increase in the rate of cropland abandonment following the 2015 earthquake in both study sites (Fig. 2), which caused serious damages in the area. Between 2006 and 2019, the trend line indicates an annual increase in cropland abandonment by 63 ropani in Kavrepalanchowk and 47 ropani in Tanahu.

\section{c. Reasons for cropland abandonment}

The reasons reported by the farmers for cropland abandonment were divided into eight broad categories: crop raiding (CR), lack of labor (LL), high opportunity cost (HC), far from house (FH), slope of land (SL), surrounding cropland (SC), lower productivity due to shading effect (SE), and other miscellaneous $(\mathrm{OM})$ factors. Figure 3 shows the frequencies of cropland parcel abandonment by year, and Fig. 4 shows the frequencies of response on the reasons for cropland abandoned during 2014-18. According to the farmers, lack of labor

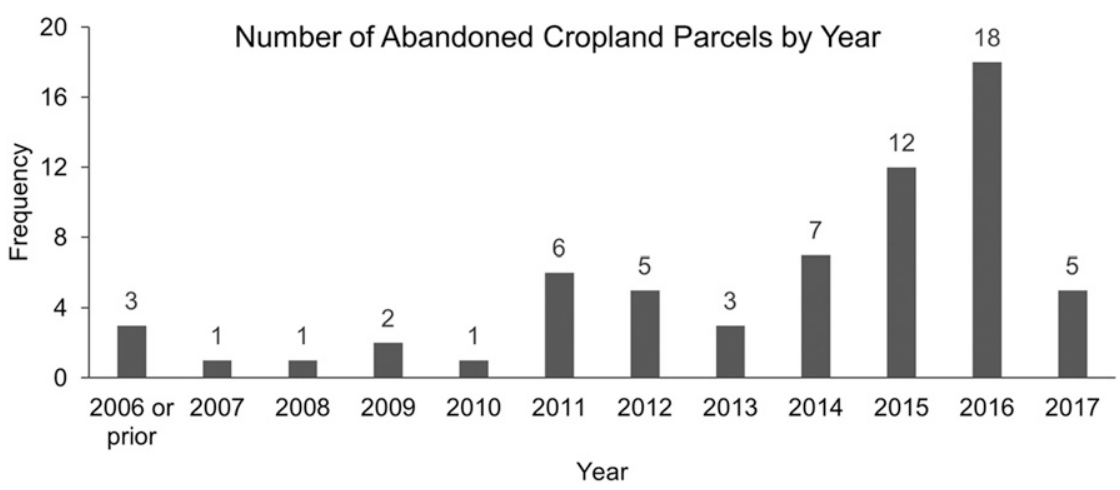

FIG. 3. Frequency of abandoned land parcels resulting from crop raiding for all years recorded in the household survey. 


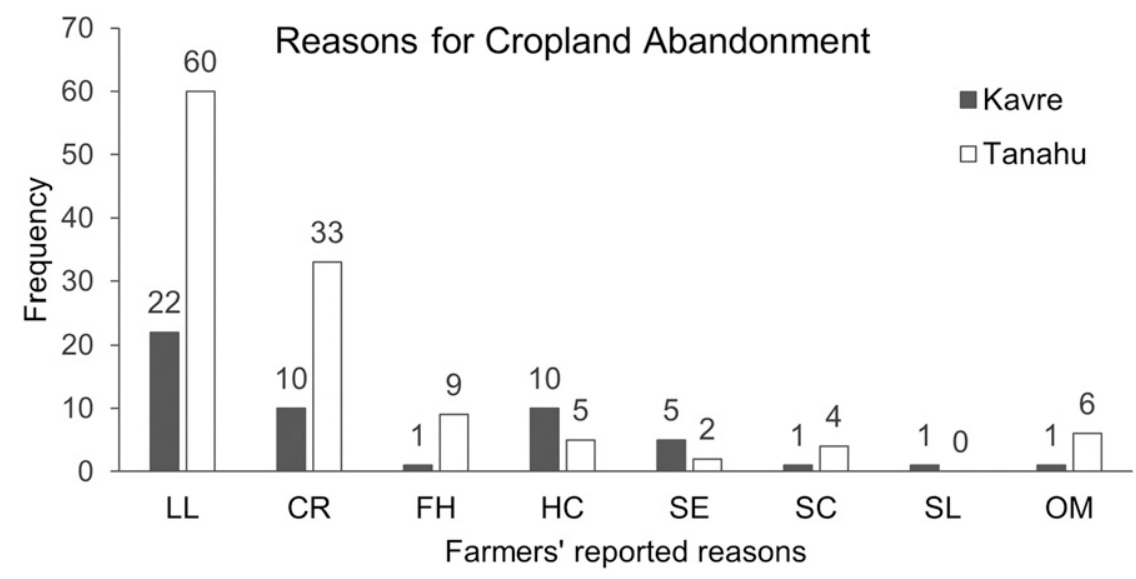

FIG. 4. Frequency of reported reasons for cropland abandonment during 2014-18. The reasons listed on the horizontal axis are lack of labor (LL), crop raiding (CR), far from house (FH), high opportunity cost (HC), lower productivity due to shading effect (SE), surrounding cropland (SC), slope of land (SL), and other miscellaneous factors (OM).

availability for agricultural works, crop raiding, and increasing opportunity cost were the most important reasons for cropland abandonment. Around $32 \%$ of cropland abandonment in Kavrepalanchowk and $40 \%$ in Tanahu, were due to a lack of agriculture labor force, likely due to out-migration. Parcel profile data show that the counts of land parcel abandoned due to the lack of labor was 82 during 2014-18 and 36 between 2006 and 2013. The comparison shows the increase in the number of cropland abandonment due to the lack of labor. Similarly, more than $15 \%$ and $21 \%$ of the abandoned cropland was due to crop raiding in Kavrepalanchowk and Tanahu, respectively. The farmers believed that the increase in community-forest area and trees in farmland over the years was a major factor for increasing incidences of crop raiding (Fig. 3). The household survey data showed that around $47 \%$ of the active land parcels in Tanahu and 30\% in Kavrepalanchowk had suffered crop raiding in the last 12 months. As shown in Fig. 3, we found an increasing trend of cropland abandonment due to crop raiding incidence in recent years. Decreasing productivity due to shading effects of forests was also reported as another reason by the farmers for cropland abandonment. Around $9 \%$ of the land in Kavrepalanchowk and 2.5\% in Tanahu was abandoned due to a decrease in productivity caused mainly by shading effects.

The opportunity cost of off-farm activities, that is, a higher rate of return relative to agricultural work, had led to around $16.0 \%$ and $4.6 \%$ of the cropland abandonment in Kavrepalanchowk and Tanahu, respectively. Participants in the focus-group discussions averred that there was a higher demand for off-farm work opportunities (e.g., house construction and other labor work) that paid double wages relative to agriculture work, especially after the 2015 earthquake. Similarly, some of the farmers $(7.5 \%$ in Kavrepalanchowk and 3.6\% in Tanahu) abandoned their cropland because the slopes of the land parcels were too steep. Around $6 \%$ of the parcels were abandoned because of being too far from home. Farmers reported that cultivation on distant land parcels was not economically viable as an increase in the distance increased the cost of transportation. We also observed the feedback effect of abandonment on adjacent land parcels. Some farmers left their cropland abandoned because of surrounding cropland being abandoned. This accounted for $5.5 \%$ and $4.0 \%$ of cropland abandonment in Kavrepalanchowk and Tanahu, respectively. Farmers reported that land parcels adjacent to abandoned parcels were more likely to have pest problems and invasive species, and the abandonment of surrounding croplands also disrupted traditional irrigation system for water flow. The effect of civil war could be clearly observed on the sociopolitical dimension of the rural community in Nepal. During the war, most of the youth and richer households fled to urban centers because of security concerns, and they rarely returned to their home villages even after the war ended. Since then, the migration trend went up as migration networks gradually got established.

\section{d. Socioecological determinants of cropland abandonment}

This section presents the multilevel logistic regression results with different sets of explanatory variables at the parcel and household levels that influence cropland abandonment. The null model, including random effects at the household level, showed that the variance at the household level was significant $(p<0.05)$, suggesting a significant difference in cropland abandonment decisions among the households. The intraclass correlation coefficient of the null model indicated that $22 \%$ of the variance could be attributed to the household level. Table 4 presents the odds ratio and its standard error of random-intercept logistic regression models, with different levels of variables incorporated. The parcel level variables such as walking distance from house locations to cropland parcels, shading effects, and the slope all significantly contributed to cropland abandonment. An increase in walking distance to the parcel of $10 \mathrm{~min}$ from home was associated with $35 \%$ increase in the odds of cropland abandonment, while the odds for land abandonment for parcels with shading were $79 \%$ higher than 
TABLE 4. Parameter estimation results (odds ratio) from multilevel model for cropland abandonment. One, two, and three asterisks indicate significance levels $p<0.05, p<0.01$, and $p<0.001$, respectively.

\begin{tabular}{|c|c|c|c|c|}
\hline \multirow[b]{2}{*}{ Variable } & \multicolumn{2}{|c|}{ Null model } & \multicolumn{2}{|c|}{ Full model } \\
\hline & Odds ratio & Std error & Odds ratio & Std error \\
\hline \multicolumn{5}{|l|}{ Level 1 (parcel level; $N=1100)$} \\
\hline Intercept & $0.11^{* * * *}$ & 0.02 & $0.01^{* * * *}$ & 0.011 \\
\hline Shading effects & & & $1.79^{*}$ & 0.40 \\
\hline Land type & & & 1.35 & 0.32 \\
\hline Distance to house location & & & $1.35^{\text {**** }}$ & 0.07 \\
\hline Elev & & & 0.95 & 0.06 \\
\hline Slope & & & $1.06^{* * * *}$ & 0.013 \\
\hline \multicolumn{5}{|l|}{ Level 2 (household level; $N=408$ ) } \\
\hline Total land area & & & $1.02^{*}$ & 0.01 \\
\hline Age & & & 0.99 & 0.01 \\
\hline Gender & & & $0.47^{*}$ & 0.13 \\
\hline Education & & & 1.05 & 0.04 \\
\hline Occupation & & & $1.75^{*}$ & 0.41 \\
\hline Site & & & 1.48 & 0.94 \\
\hline Internal migrants & & & $1.20^{*}$ & 0.08 \\
\hline \multicolumn{5}{|l|}{ Caste: Brahmin/Chhetri (base) } \\
\hline Caste: Dalit & & & 0.50 & 0.17 \\
\hline Caste: Janajati & & & $1.73^{* *}$ & 0.49 \\
\hline Household variance & 0.95 & 0.34 & 0.55 & 0.32 \\
\hline Akaike information criterion & 893.35 & & 799.82 & \\
\hline Intraclass correlation & 0.22 & & 0.14 & 0.07 \\
\hline ROC & & & 76 & \\
\hline
\end{tabular}

the odds for a parcel without shading. A unit increase in the slope increased the odds of cropland abandonment by $6 \%$. Elevation and land type did not have significant effects on cropland abandonment. At the household level, total agriculture land owned, occupation, caste group, number of internal migrants showed significant influences on cropland abandonment. A unit increase in the number of internal migrants in the household increased the odds of cropland abandonment by $20 \%$. Every unit increase in cropland area at the household level increased the odds of cropland abandonment by $2 \%$. The odds for cropland abandonment for the household head without agriculture occupation were $75 \%$ higher than the odds for the household head with agriculture occupation. With reference to the odds of Brahmin/Chhetri caste household, the odds for cropland abandonment were $73 \%$ higher for the Janajati caste. This could be because the Janajati caste group had a higher number of migrants relative to other caste groups. At the same time, the odds for land abandonment for the maleheaded household was $47 \%$ lower than odds for the femaleheaded households. The ROC curve value for the model was $76 \%$, which indicates that the selected independent variables adequately explained cropland abandonment. The likelihood ratio test statistics $\left(\chi^{2}=84.38 ; p<0.001\right)$ indicates that the random coefficient logistic regression model fit significantly better than the ordinary logistic regression.

\section{Discussion}

This study finds that household and parcel level characteristics significantly influence the likelihood of cropland abandonment in the Middle Hills of Nepal. The results advanced our understanding of cropland abandonment from four major interrelated aspects. First, this study used both qualitative and quantitative approaches for the analysis. Most of the earlier studies adopted a qualitative approach to understand cropland abandonment and those few studies that used quantitative measures either aggregated or disaggregated data at a single level, resulting in bias in modeling the effects of factors at multiple levels on land-use decisions (Guo and Zhao 2000; Overmars and Verburg 2006). Second, this study collected a significant number of household data and parcel GPS coordinates, allowing better modeling the determinants of cropland abandonment with direct linkage between households and cropland parcels. Third, our model included many socioeconomic and biophysical factors at multiple levels and hence overcame the limitation of the studies that focused on only agriculture labor migration at the macro scale. Fourth, this study identified crop raiding and forest shading effects as feedback mechanisms from community forests to cropland abandonment. Such feedback mechanisms were not investigated before, yet of critical relevance to forest policy.

\section{a. Cropland abandonment reported reasons}

Understanding the farmers' knowledge on what caused cropland abandonment is crucial for agricultural and policy development and implementation for better natural resource management (Blair et al. 2018; Rajpar et al. 2019). Among all abandoned cropland parcels, lack of farm labor and crop raiding were reported as the two dominant reasons for cropland abandonment, which is consistent with findings in previous studies that concluded the lack of farm labor due to out-migration and shifting occupations were the major reasons 


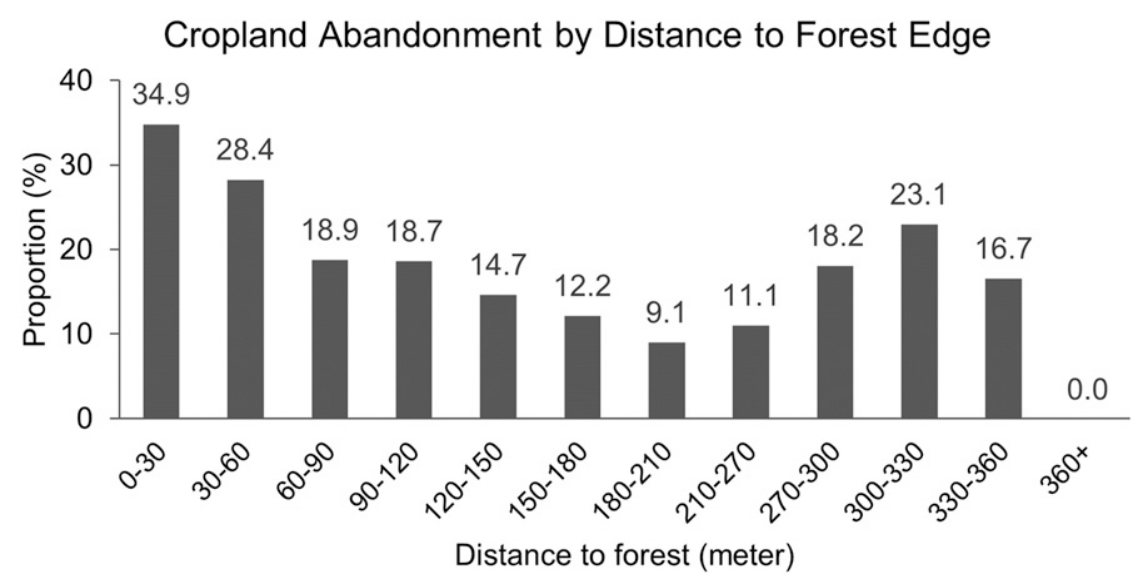

FIG. 5. Proportion of abandoned land parcel vs distance to the forest edge.

for cropland abandonment (Bhawana and Race 2020a; Blair et al. 2018; Rai et al. 2019; Wang et al. 2017; L. Zhang et al. 2018; Q. Zhang et al. 2018).

In line with the government study (Department of Forest Research and Survey 2015; Ministry of Forests and Soil Conservation 2013), farmers reported that forest quality and quantity have enhanced during the community-forestry program, which has resulted in increased incidences of crop raiding by wildlife. This in turn discouraged people from pursuing agriculture in areas with high risk of crop raiding (Bhawana and Race 2020a), as also observed elsewhere around the world (Hua et al. 2016; Wang et al. 2020; Yan et al. 2016; L. Zhang et al. 2018; Q. Zhang et al. 2018). Study has suggested that crop raiding by wildlife due to conservation programs could offset household livelihoods and hence undermine the economic benefits of the programs (Chen et al. 2018). Farmers perceived that cropland parcels close to forests yielded less due to shading effects from trees. Other empirical studies conducted in the Middle Hill regions of Nepal reported reduction in maize and millet production by the tree shade (Amatya et al. 2018; Tiwari et al. 2012). Such adverse shading effects, especially from trees with dense canopy, have also been confirmed in countries other than Nepal (Tiwari et al. 2012) as well as on a variety of crops such as rice panicles and spikelets, maize, wheat, and legumes (Jose et al. 2008; Lin et al. 1998; Miyagawa et al. 2017; Sharif et al. 2010; Suryanto et al. 2014). In this study, farmers acknowledged that the lack of proper forest management activities (e.g., thinning and pruning) contributed to the increased phenomenon of tree shading and incidences of crop raiding.

\section{b. Cropland parcel attributes and household characteristics}

Our modeling results showed a positive association between cropland abandonment and area of the parcels owned by households, as also found in other regions (e.g., Zhou et al. 2020). Meanwhile, our model did not find significant difference in cropland abandonment between different cropland types. This may be due to the confounding effect of traveling time from the parcel to the household residence (Paudel et al. 2014; Wang et al. 2020; L. Zhang et al. 2018; Q. Zhang et al. 2018).
Abandoned croplands in earlier years were mostly marginal and distant land parcels, but in recent years, fertile croplands are increasingly being abandoned (Gilmour et al. 2014; Paudel et al. 2014) due to a multitude of factors as analyzed in the model above. Increased rate of cropland abandonment is associated with an increase in the slopes of the land (Zhang et al. 2014). Agricultural practices on steep slopes have a higher ecological cost with lower returns. Cultivating crops on steep slopes demands more terracing, which is very labor intensive, and yet the terraced cropland is less efficient for using agriculture tools (Prishchepov et al. 2011; Su et al. 2018), making the agriculture lands on slopes more susceptible to be abandoned.

Households are regarded as the decision-makers for land use (L. Zhang et al. 2018; Q. Zhang et al. 2018). In this case, cropland abandonment is shown directly related to the demographic characteristics of the owner households ( $\mathrm{Li}$ et al. 2018), namely farm labor availability that is key to the farm work in technology-deficient countries like Nepal. Likewise, rural-to-urban migration reduces the availability of farm labor, thus increasing the likelihood of cropland abandonment, as concluded in many studies (Jaquet et al. 2015; López et al. 2006; Paudel et al. 2014; Xu et al. 2019). Meanwhile, the phenomenon termed "feminization of agriculture work" (Han and Song 2019; Ojha et al. 2017; Paudel et al. 2014) that results from out-migration by the male labor is manifested by our result: land abandonment rate is higher in female-headed households than in male-headed households. The engagement of off-farm employment is equally important in decisions on cropland abandonment in some other studies (Deng et al. 2018; Du et al. 2019; Rai et al. 2019), but it is not considered here, because in Nepal a significant share of the rural income is contributed by remittances, pensions, and/or governmental elderly allowances (Gilmour et al. 2014). The socially enrooted caste system is also a major factor driving agrarian practices in Nepal (Sunam 2020). Households in the higher caste group have comparatively large areas of landholding with alternatives to agriculture-based livelihoods (Central Bureau of Statistics 2016), which provides more leverage to leave their land abandoned. 


\section{c. Natural system and cropland abandonment}

Theories on land-use change have not fully recognized the role of feedbacks from natural systems to agricultural land use (Lambin et al. 2003). Our study highlights the feedback effects of a natural system on cropland abandonment, mediated by crop raiding and shading effects from forest aggradation due to community-forestry practice. The decreasing proportion of abandoned land parcel with increase in distance to the forest edge (Fig. 5) is because the land parcels close to forests have a higher incidence of crop raiding (Bhawana and Race 2020a; Hua et al. 2016) and experience a shading effect from the trees to the agriculture crops, resulting in lower productivity (Miyagawa et al. 2017; Schmidt et al. 2019; Suryanto et al. 2014). Of the 1100 cropland parcels used in our models, 367 land parcels were within the range of shading effects from the forest edge. As shown in Fig. 5, the likelihood of cropland abandonment decreases as the croplands get farther away from forest edge to as far as $200 \mathrm{~m}$, mostly due to the decreasing impacts of crop raiding. Beyond this distance, the cropland abandonment phenomenon could be influenced by other factors. Of the total 341 abandoned land parcels, 19\% (65) was due to wildlife crop raiding. Corn, rice, wheat, and millet (major cereal crops) were the crops most affected by monkeys, wild boars, porcupines, deer, and bears in the study sites. Survey data showed that $40 \%$ of the total surveyed land parcels had experienced different levels of crop raiding. Crop damage by wild animals was more likely to occur within approximately $200 \mathrm{~m}$ from the forest edge (Naughton-Treves 1997; Wallace and Hill 2012) and is a major reason behind the higher proportions of cropland abandonment. The 200-m range agrees well with the findings reported in other literature.

\section{Final remarks}

In this study, we examined the current state of cropland use and quantitatively analyzed the influence of socioeconomic, biophysical, and institutional factors on cropland abandonment in the Middle Hills of Nepal, where community forests are an integral part of the agricultural landscape. We found an increasing trend of cropland abandonment due to multiple factors at the parcel and household levels, posing a serious threat to food security in Nepal. Above $26 \%$ of the land parcels were abandoned in our study sites. At the parcel level, slope, walking distance to the cropland parcels, and shading effects were major determinants of cropland abandonment. At the household level, occupation of household head, labor migration, gender, amount of agricultural landholding, and caste significantly affected cropland abandonment. Farmers' reported reasons for cropland abandonment confirmed these findings; that is, lack of labor and crop raiding are the dominant factors contributing to cropland abandonment. A major theoretical contribution that this study made is the identification of the feedback mechanisms of crop raiding and shading effects from community forests to land-use change, and these feedback effects from the natural system should be considered when investigating the farmers' land-use decisions. These findings have significant implications for making new land-use policies aiming at addressing cropland abandonment phenomenon to secure food supply in Nepal.

Acknowledgments. This research is partially supported by a National Science Foundation grant (ICER-2108238) and the Stephen Birdsall Summer Fellowship awarded to author Bista in the Department of Geography at UNC-Chapel Hill and by a UNC internal grant awarded to Dr. Conghe Song. We thank Dr. Naya Sharma Paudel at ForestAction, Nepal, and Chief District Forest Officer (Tanahu) Kedar Baral for their assistance for logistic arrangement, field enumerators for data collection, and all of the community people for their time in participating in this study. Thanks are also given to two anonymous reviewers for providing valuable and constructive comments.

\section{REFERENCES}

Alcantara, C., and Coauthors, 2013: Mapping the extent of abandoned farmland in central and eastern Europe using MODIS time series satellite data. Environ. Res. Lett., 8, 035035, https:// doi.org/10.1088/1748-9326/8/3/035035.

Amatya, S. M., E. Cedamon, and I. Nuberg, 2018: Agroforestry systems and practices in Nepal. Agriculture and Forestry University Rep., 188 pp.

Anup, K. C., 2017: Community forestry management and its role in biodiversity conservation in Nepal. Global Exposition of Wildlife Management, S. A. L. Gbolagade, Ed., INTECH, 51-72.

Baxter, R. E., and K. E. Calvert, 2017: Estimating available abandoned cropland in the United States: Possibilities for energy crop production. Ann. Assoc. Amer. Geogr., 107, 11621178, https://doi.org/10.1080/24694452.2017.1298985.

Benayas, J. M. R., A. Martins, J. M. Nicolau, and J. J. Schulz, 2007: Abandonment of agricultural land: An overview of drivers and consequences. CAB Rev., 2, 057, https://doi.org/10.1079/ PAVSNNR20072057.

Bhattarai, K., and D. Conway, 2021: Contemporary Environmental Problems in Nepal: Geographic Perspectives. Advances in Asian Human-Environmental Research Series, Springer Nature, 764 pp.

—, M. Yousef, A. Greife, and S. C. S. Naraharisetti, 2020: Influence of topography on sustainable land management: An analysis of socioeconomic and ecodemographic conditions of Nepal. Agriculture, 10, 224, https://doi.org/10.3390/agriculture10060224.

Bhawana, K. C., and D. Race, 2020a: Outmigration and land-use change: A case study from the Middle Hills of Nepal. Land, $\mathbf{9}$, 2, https://doi.org/10.3390/land9010002.

, and - 2020b: Women's approach to farming in the context of feminization of agriculture: A case study from the Middle Hills of Nepal. World Dev. Perspect., 20, 100260, https:// doi.org/10.1016/j.wdp.2020.100260.

Blair, D., C. M. Shackleton, and P. J. Mograbi, 2018: Cropland abandonment in South African smallholder communal lands: Land cover change (1950-2010) and farmers perceptions of contributing factors. Land, 7, 121, https://doi.org/10.3390/ land7040121.

Bowen, M. E., C. A. McAlpine, A. P. N. House, and G. C. Smith, 2007: Regrowth forests on abandoned agricultural land: A review of their habitat values for recovering forest fauna. Biol. Conserv., 140, 273-296, https://doi.org/10.1016/j.biocon.2007.08.012.

Campbell, J. E., D. B. Lobell, R. C. Genova, and C. B. Field, 2008: The global potential of bioenergy on abandoned agriculture 
lands. Environ. Sci. Technol., 42, 5791-5794, https://doi.org/ 10.1021/es800052w.

Central Bureau of Statistics, 2016: Annual household survey 2015/ 16. Vol. 16, Government of Nepal Doc., 43 pp., https:// reliefweb.int/sites/reliefweb.int/files/resources/AnnualHousehold Survey 2015_16_Major findings.pdf.

Chalise, D., L. Kumar, and P. Kristiansen, 2019: Land degradation by soil erosion in Nepal: A review. Soil Syst., 3, 12, https:// doi.org/10.3390/soilsystems3010012.

Chaudhary, S., and Coauthors, 2018: Social impact of farmland abandonment and its eco-environmental vulnerability in the high mountain region of Nepal: A case study of Dordi River Basin. Sustainability, 10, 2331, https://doi.org/10.3390/su10072331.

—-, Y. Wang, A. M. Dixit, and N. R. Khanal, 2020: A synopsis of farmland abandonment and its driving factors in Nepal. Land, 9, 84, https://doi.org/10.3390/land9030084.

Chen, X., Q. Zhang, M. N. Peterson, and C. Song, 2018: Feedback effect of crop raiding in payments for ecosystem services. Ambio, 48, 732-740, https://doi.org/10.1007/s13280-018-1105-0.

de Jong, W., J. Liu, M. S. Park, and L. Camacho, 2017: Forest transition in Asia: Trends and some theoretical implications. For. Policy Econ., 76, 1-6, https://doi.org/10.1016/ j.forpol.2016.11.007.

Deng, X., D. Xu, Y. Qi, and M. Zeng, 2018: Labor off-farm employment and cropland abandonment in rural China: Spatial distribution and empirical analysis. Int. J. Environ. Res. Public Health, 15, 1808, https://doi.org/10.3390/ijerph15091808.

Department of Forest Research and Survey, 2015: State of Nepal's forests. Government of Nepal Ministry of Forests and Soil Conservation Doc., 70 pp., https://frtc.gov.np/downloadfile/ state_forest_of_Nepal_1579793749_1579844506.pdf.

Deshar, B. D., 2013: An overview of agricultural degradation in Nepal. Global J. Econ. Soc. Dev., 3, 1-20.

Dhruba Bijaya, G. C., S. Cheng, Z. Xu, J. Bhandari, L. Wang, and X. Liu, 2016: Community forestry and livelihood in Nepal: A review. J. Anim. Plant Sci., 26, 1-12.

Díaz, G. I., L. Nahuelhual, C. Echeverría, and S. Marín, 2011: Landscape and urban planning drivers of land abandonment in southern Chile and implications for landscape planning. Landscape Urban Plan., 99, 207-217, https://doi.org/10.1016/ j.landurbplan.2010.11.005.

District Forest Office, 2018: Community Forest Development Program monitoring and evaluation report. Nepal Kavrepalanchowk District Rep., 125 pp.

_ 2019: Community Forest Development Program monitoring and evaluation report. Nepal Tanahu District Rep., 80 pp.

Du, J., M. Zeng, Z. Xie, and S. Wang, 2019: Power of agricultural credit in farmland abandonment: Evidence from rural China. Land, 8, 184, https://doi.org/10.3390/land8120184.

Fischer, J., and Coauthors, 2008: Should agricultural policies encourage land sparing or wildlife-friendly farming? Front. Ecol. Environ., 6, 380-385, https://doi.org/10.1890/070019.

Forest Research and Training Centre, 2019: National level forests and land cover analysis of Nepal using Google Earth images. Government of Nepal Doc., 41 pp., http://frtc.gov.np/old/ downloadfile/Forest_and_Land_Cover_Analysis_final_report_ 1550056440.pdf.

Gauchan, D., 2018: Agricultural development in Nepal: Emerging challenges and opportunities. Discourses on Nepal's Development, K. Suman and M. Khatri, Eds., Vol. 2, Nepal Policy Research Center, 212-240.

Geist, H. J., and E. F. Lambin, 2002: Proximate causes and underlying driving forces of tropical deforestation. BioScience,
52, 143, https://doi.org/10.1641/0006-3568(2002)052[0143: PCAUDF]2.0.CO;2.

Gilmour, D., U. Prabhan, Y. Malla, T. Bartlett, R. Finlayson, and R. Shah, 2014: Enhancing livelihoods and food security from agroforestry and community forestry systems in Nepal: Current status, trends, and future directions. World Agroforestry Centre Rep., 130 pp., http://apps.worldagroforestry.org/sea/Publications/ files/report/RP0306-15.pdf.

Goswami, V. R., S. Sridhara, K. Medhi, A. C. Williams, R. Chellam, J. D. Nichols, and M. K. Oli, 2014: Community-managed forests and wildlife-friendly agriculture play a subsidiary but not substitutive role to protected areas for the endangered Asian elephant. Biol. Conserv., 177, 74-81, https://doi.org/10.1016/ j.biocon.2014.06.013.

Guo, G., and H. Zhao, 2000: Multilevel modelling for binary data. Annu. Rev. Sociol., 26, 441-462, https://doi.org/10.1146/ annurev.soc.26.1.441.

Han, Z., and W. Song, 2019: Spatiotemporal variations in cropland abandonment in the Guizhou-Guangxi karst mountain area, China. J. Cleaner Prod., 238, 117888, https://doi.org/10.1016/ j.jclepro.2019.117888.

He, Y., H. Xie, and C. Peng, 2020: Analyzing the behavioural mechanism of farmland abandonment in the hilly mountainous areas in China from the perspective of farming household diversity. Land Use Policy, 99, 104826, https://doi.org/10.1016/ j.landusepol.2020.104826.

Hobbs, R. J., and V. A. Cramer, 2007: Why old fields? Socioeconomic and ecological cause and consequencs of land abandonment. Old Fields: Dynamics and Restoration of Abandoned Farmland, Island Press, 1-14.

Hua, X., J. Yan, H. Li, W. He, and X. Li, 2016: Wildlife damage and cultivated land abandonment: Findings from the mountainous areas of Chongqing, China. Crop Prot., 84, 141-149, https:// doi.org/10.1016/j.cropro.2016.03.005.

Islam, M. M., A. Jannat, A. R. Dhar, and T. Ahamed, 2019: Factors determining conversion of agricultural land use in Bangladesh: Farmers' perceptions and perspectives of climate change. GeoJournal, 85, 343-362, https://doi.org/10.1007/s10708-01809966-w.

Jaquet, S., G. Schwilch, F. Hartung-Hofmann, A. Adhikari, K. Sudmeier-Rieux, G. Shrestha, H. P. Liniger, and T. Kohler, 2015: Does outmigration lead to land degradation? Labour shortage and land management in a western Nepal watershed. Appl. Geogr., 62, 157-170, https://doi.org/10.1016/ j.apgeog.2015.04.013.

- T. Kohler, and G. Schwilch, 2019: Labour migration in the Middle Hills of Nepal: Consequences on land management strategies. Sustainability, 11, 1349, https://doi.org/10.3390/ su11051349.

Jefferson, F., R. R. Rindfuss, S. J. Walsh, and V. Mishra, Eds., 2004: People and Environment Approaches for Linking Household and Community Survey to Remote Sensing and GIS. Kluwer Academic, 344 pp.

Jose, S., S. C. Allen, and R. P. K. Nair, 2008: Tree-crop interactions: Lessons from temperate alley-cropping systems. D. R. Batish et al., Eds., Ecological Basis of Agroforestry, Taylor and Francis, 15-36.

Karki, R., K. K. Shrestha, H. Ojha, N. Paudel, D. B. Khatri, I. Nuberg, and A. Adhikary, 2018: From forests to food security: Pathways in Nepal's community forestry. Small-Scale For., 17, 89-104, https://doi.org/10.1007/s11842-017-9377-y.

Kerckhof, A., V. Spalevic, V. Van Eetvelde, and J. Nyssen, 2016: Factors of land abandonment in mountainous Mediterranean 
areas: The case of Montenegrin settlements. SpringerPlus, $\mathbf{5}$, 485, https://doi.org/10.1186/s40064-016-2079-7.

Khanal, N. R., and T. Watanabe, 2006: Abandonment of agriculture land and its consequences: A case study in the Sikles Area, Gandaki Basin, Nepal Himalaya. Mt. Res. Dev., 26, 80-81, https://doi.org/ 10.1659/0276-4741(2006)026[0032:AOALAI]2.0.CO;2.

Khanal, U., 2018: Why are farmers keeping cultivatable lands fallow even though there is food scarcity in Nepal? Food Secur., 10, 603-614, https://doi.org/10.1007/s12571-018-0805-4.

Lambin, E. F., and P. Meyfroidt, 2010: Land use transitions: Socioecological feedback versus socio-economic change. Land Use Policy, 27, 108-118, https://doi.org/10.1016/j.landusepol.2009.09.003.

—_, and Coauthors, 2001: The causes of land-use and landcover change: Moving beyond the myths. Global Environ. Change, 11, 261-269, https://doi.org/10.1016/S0959-3780(01) 00007-3.

- , H. J. Geist, and E. Lepers, 2003: Dynamics of land use and landcover change in tropical regions. Annu. Rev. Environ. Resour., 28, 205-241, https://doi.org/10.1146/annurev.energy.28.050302.105459.

Leal Filho, W., M. Mandel, A. Q. Al-Amin, A. Feher, and C. J. Chiappetta Jabbour, 2017: An assessment of the causes and consequences of agricultural land abandonment in Europe. Int. J. Sustainable Dev. World Ecol., 24, 554-560, https:// doi.org/10.1080/13504509.2016.1240113.

Li, S., and X. Li, 2017: Global understanding of farmland abandonment: A review and prospects. J. Geogr. Sci., 27, 11231150, https://doi.org/10.1007/s11442-017-1426-0.

,,-- L. Sun, G. Cao, G. Fischer, and S. Tramberend, 2018: An estimation of the extent of cropland abandonment in mountainous regions of China. Land Degrad. Dev., 29, 13271342, https://doi.org/10.1002/ldr.2924.

Lin, C. H., R. L. McGraw, M. F. George, and H. E. Garrett, 1998: Shade effects on forage crops with potential in temperate agroforestry practices. Agrofor. Syst., 44, 109-119, https:// doi.org/10.1023/A:1006205116354.

Liu, J., S. Li, Z. Ouyang, C. Tam, and X. Chen, 2008: Ecological and socioeconomic effects of China's policies for ecosystem services. Proc. Natl. Acad. Sci. USA, 105, 9477-9482, https:// doi.org/10.1073/pnas.0706436105.

López, E., G. Bocco, M. Mendoza, A. Velázquez, and J. Rogelio Aguirre-Rivera, 2006: Peasant emigration and land-use change at the watershed level: A GIS-based approach in central Mexico. Agric. Syst., 90, 62-78, https://doi.org/10.1016/j.agsy.2005.11.001.

Malek, Ž., B. Douw, J. Van Vliet, E. H. Van Der Zanden, and P. H. Verburg, 2019: Local land-use decision-making in a global context. Environ. Res. Lett., 14, 083006, https://doi.org/10.1088/ 1748-9326/ab309e.

Ministry of Agricultural Development, 2015: Agriculture development strategy (ADS) 2015 to 2035 part: 1 . Government of Nepal Rep., 363 pp., http://extwprlegs1.fao.org/docs/ pdf/nep171433.pdf.

Ministry of Agriculture and Livestock Development, 2020: Statistical information in Nepalese agriculture 2075/76 [2018/19]. Government of Nepal Doc., 437 pp., https://s3-ap-southeast1.amazonaws.com/prod-gov-agriculture/server-assets/publication1595229368881-0dc12.pdf.

Ministry of Forests and Soil Conservation, 2013: Persistence and change: Review of 30 years of community forestry in Nepal. Government of Nepal Doc., 17 pp.

Miyagawa, S., M. Kobayashi, and H. T. Pham, 2017: Effects of trees planted on levees on rice yields in rain-fed paddy fields of northeast Thailand. Plant Prod. Sci., 20, 47-54, https://doi.org/ 10.1080/1343943X.2016.1260483.
Narendra, A., R. Khanal, and T. Watanabe, 2019: Abandonment of agricultural land and its consequences. Mt. Res. Dev., 26, 32-40, https://doi.org/10.1659/0276-4741(2006)026[0032: AOALAI]2.0.CO;2.

National Planning Commission, 2019: The fifteenth plan (fiscal year 2019/20-2023/24). Government of Nepal Doc., 731 pp, https://npc.gov.np/images/category/15th_plan_English_ Version.pdf.

Naughton-Treves, L., 1997: Farming the forest edge: Vulnerable places and people around Kibale National Park, Uganda. Geogr. Rev., 87, 27, https://doi.org/10.2307/215656.

_ A. Treves, C. Chapman, and R. Wrangham, 1998: Temporal patterns of crop-raiding by primates: Linking food availability in croplands and adjacent forest. J. Appl. Ecol., 35, 596-606, https://doi.org/10.1046/j.1365-2664.1998.3540596.x.

Naya, P. S., B. P. Badri, R. Karki, and R. Bista, 2014: Drivers and dynamics of agrarian change in Nepal. Enhancing Livelihoods and Food Security from Agroforestry and Community Forestry Systems in Nepal: Current Status, Trends, and Future Directions, D. Gilmour et al., Eds., World Agroforestry Centre, 35-50.

Ojha, H. R., and Coauthors, 2017: Agricultural land underutilisation in the hills of Nepal: Investigating socio-environmental pathways of change. J. Rural Stud., 53, 156-172, https://doi.org/ 10.1016/j.jrurstud.2017.05.012.

Overmars, K. P., and P. H. Verburg, 2006: Multilevel modelling of land use from field to village level in the Philippines. Agric. Syst., 89, 435-456, https://doi.org/10.1016/j.agsy.2005.10.006.

Pan, W. K. Y., and R. E. Bilsborrow, 2005: The use of a multilevel statistical model to analyze factors influencing land use: A study of the Ecuadorian Amazon. Global Planet. Change, 47, 232-252, https://doi.org/10.1016/j.gloplacha.2004.10.014.

Paudel, B., Y. Zhang, J. Yan, R. Rai, and L. Li, 2019: Farmers' perceptions of agricultural land use changes in Nepal and their major drivers. J. Environ. Manage., 235, 432-441, https:// doi.org/10.1016/j.jenvman.2019.01.091.

- and Coauthors, 2020: Farmland abandonment and its determinants in the different ecological villages of the Koshi river basin, central Himalayas: Synergy of high-resolution remote sensing and social surveys. Environ. Res., 188, 109711, https:// doi.org/10.1016/j.envres.2020.109711.

Paudel, K. P., S. Tamang, and K. K. Shrestha, 2014: Transforming land and livelihood: Analysis of agricultural land abandonment in the mid hills of Nepal. J. For. Livelihood, 12, 11-19.

Prishchepov, A. V., V. C. Radeloff, D. Muller, M. Dubinin, and M. Baumann, 2011: Determinants of agricultural land abandonment in post-Soviet European Russia. EAAE 2011 Congress, Zurich, Switzerland, European Association of Agricultural Economists, https://doi.org/10.22004/ag.econ.120390.

Priston, N. E. C., and S. J. Underdown, 2009: A simple method for calculating the likelihood of crop damage by primates: An epidemiological approach. Int. J. Pest Manage., 55, 51-56, https://doi.org/10.1080/09670870802450268.

Rai, R., Y. Zhang, B. Paudel, and N. R. Khanal, 2019: Status of farmland abandonment and its determinants in the transboundary Gandaki River Basin. Sustainability, 11, 5267, https://doi.org/10.3390/su11195267.

Rajpar, H., A. Zhang, A. Razzaq, K. Mehmood, M. B. Pirzado, and W. Hu, 2019: Agricultural land abandonment and farmers' perceptions of land use change in the Indus plains of Pakistan: A case study of Sindh province. Sustainability, 11, 4663, https:// doi.org/10.3390/su11174663.

Rindfuss, R. R., 2008: Land use change: Complexity and comparisons. J. Land Use Sci., 3, 1-10, https://doi.org/10.1080/17474230802047955. 
— S. J. Walsh, B. L. Turner, J. Fox, and V. Mishra, 2004: Developing a science of land change: Challenges and methodological issues. Proc. Natl. Acad. Sci. USA, 101, 1397613 981, https://doi.org/10.1073/pnas.0401545101.

Rudel, T. K., O. T. Coomes, E. Moran, F. Achard, A. Angelsen, J. Xu, and E. Lambin, 2005: Forest transitions: Towards a global understanding of land use change. Global Environ. Change, 15, 23-31, https://doi.org/10.1016/j.gloenvcha.2004.11.001.

Schmidt, M., C. Nendel, R. Funk, M. G. E. Mitchell, and G. Lischeid, 2019: Modeling yields response to shading in the field-to-forest transition zones in heterogeneous landscapes. Agriculture, 9, 6, https://doi.org/10.3390/agriculture9010006.

Schuster, R., R. R. Germain, J. R. Bennett, N. J. Reo, and P. Arcese, 2019: Vertebrate biodiversity on indigenousmanaged lands in Australia, Brazil, and Canada equals that in protected areas. Environ. Sci. Policy, 101, 1-6, https:// doi.org/10.1016/j.envsci.2019.07.002.

Schwilch, G., and Coauthors, 2017: Impacts of outmigration on land management in a Nepali mountain area. Identifying Emerging Issues in Disaster Risk Reduction, Migration, Climate Change and Sustainable Development, K. SudmeierRieux et al. Eds., Springer, 177-194, https://doi.org/10.1007/ 978-3-319-33880-4_11.

Sharif, O. M., R. M. Mondol, and M. Wadud, 2010: Effect of shade of different trees on growth and yield of Aman rice. J. Agrofor. Environ., 4, 167-172.

Shi, T., X. Li, L. Xin, and X. Xu, 2016: Analysis of farmland abandonment at parcel level: A case study in the mountainous area of China. Sustainability, 8, 988, https://doi.org/10.3390/ su8100988.

Shrestha, T. K., and G. Paudel, 2018: Crop depredation by monkey outside protected area in Nepal: Costs, conditions and perceptions. Indian For., 144, 929-935.

Sommet, N., and D. Morselli, 2017: Keep calm and learn multilevel logistic modeling: A simplified three-step procedure using Stata, R, Mplus, and SPSS. Rev. Int. Psychol. Soc., 30, 203-218, https://doi.org/10.5334/irsp.90.

Su, G., H. Okahashi, and L. Chen, 2018: Spatial pattern of farmland abandonment in Japan: Identification and determinants. Sustainability, 10, 3676, https://doi.org/10.3390/ su10103676.

Sunam, R., 2020: Transnational Labour Migration, Livelihoods and Agrarian Change in Nepal. Routledge, 140 pp.

Suryanto, P., E. T. S. Putra, S. Kurniawan, B. Suwignyo, and D. A. P. Sukirno, 2014: Maize response at three levels of shade and its improvement with intensive agro forestry regimes in Gunung Kidul, Java, Indonesia. Procedia Environ. Sci., 20, 370-376, https://doi.org/10.1016/j.proenv.2014.03.047.

Tiwari, T. P., R. M. Brook, P. Wagstaff, and F. L. Sinclair, 2012: Effects of light environment on maize in hillside agroforestry systems of Nepal. Food Secur., 4, 103-114, https://doi.org/ 10.1007/s12571-012-0165-4.

Turner, B. L., E. F. Lambin, and A. Reenberg, 2007: The emergence of land change science for global environmental change and sustainability. Proc. Natl. Acad. Sci. USA, 104, $20666-$ 20 672, https://doi.org/10.1073/pnas.0704119104.

—, P. Meyfroidt, T. Kuemmerle, D. Müller, and R. Roy Chowdhury, 2020: Framing the search for a theory of land use. J. Land Use Sci., 15, 489-508, https://doi.org/10.1080/ 1747423X.2020.1811792.

van Vliet, J., H. L. F. de Groot, P. Rietveld, and P. H. Verburg, 2015: Manifestations and underlying drivers of agricultural land use change in Europe. Landscape Urban Plann., 133, 24 36, https://doi.org/10.1016/j.landurbplan.2014.09.001.

Wallace, G. E., and C. M. Hill, 2012: Crop damage by primates: Quantifying the key parameters of crop-raiding events. PLOS ONE, 7, e46636, https://doi.org/10.1371/journal.pone.0046636.

Wang, X., X. Li, M. Tan, L. Xin, R. Wang, and S. Li, 2017: Hierarchical determinants of winter wheat abandonment in the North China Plain: A case study of Xingzhuangzi village in Hebei Province. NJAS Wagening. J. Life Sci., 80, 49-56, https://doi.org/10.1016/j.njas.2016.11.005.

Wang, Y., X. Li, L. Xin, and M. Tan, 2020: Farmland marginalization and its drivers in mountainous areas of China. Sci. Total Environ., 719, 135132, https://doi.org/10.1016/j.scitotenv.2019.135132.

Xu, D., X. Deng, K. Huang, Y. Liu, Z. Yong, and S. Liu, 2019: Relationships between labor migration and cropland abandonment in rural China from the perspective of village types. Land Use Policy, 88, 104164, https://doi.org/10.1016/ j.landusepol.2019.104164.

Yan, J., Z. Yang, Z. Li, X. Li, L. Xin, and L. Sun, 2016: Drivers of cropland abandonment in mountainous areas: A household decision model on farming scale in southwest China. Land Use Policy, 57, 459-469, https://doi.org/10.1016/j.landusepol.2016.06.014.

Zhang, L., C. Liao, H. Zhang, and X. Hua, 2018: Multilevel modeling of rural livelihood strategies from peasant to village level in Henan Province, China. Sustainability, 10, 2967, https:// doi.org/10.3390/su10092967.

Zhang, Q., C. Song, and X. Chen, 2018: Effects of China's payment for ecosystem services programs on cropland abandonment: A case study in Tiantangzhai Township, Anhui, China. Land Use Policy, 73, 239-248, https://doi.org/10.1016/ j.landusepol.2018.01.001.

Zhang, Y., X. Li, and W. Song, 2014: Land use policy determinants of cropland abandonment at the parcel, household and village levels in mountain areas of China: A multi-level analysis. Land Use Policy, 41, 186-192, https://doi.org/10.1016/j.landusepol.2014.05.011.

Zhou, T., E. Koomen, and X. Ke, 2020: Determinants of farmland abandonment on the urban-rural fringe. Environ. Manage., 65, 369-384, https://doi.org/10.1007/s00267-020-01258-9. 